\title{
Drug Utilization Study at Tertiary Care Hospitals in Punjab
}

\author{
Amit Sharma ${ }^{1}$, Ashish Baldi ${ }^{2 *}$ and Dinesh Kumar Sharma ${ }^{3}$ \\ ${ }^{1}$ Research Scholar, Uttarakhand Technical University, Dehradun, UK \& Associate Professor, Department of Pharmacy Practice, ISF College of Pharmacy, \\ Moga, (Punjab) India.
}

${ }^{2}$ Professor, Department of Pharmaceutical Science and Technology, Maharaja Ranjit Singh Punjab Technical University, Bathinda (Punjab) India.

${ }^{3}$ Principal, Devsthali Vidyapeeth College of Pharmacy, (UK) India

Submission: August 30, 2017; Published: November 20, 2017

"Corresponding author: Ashish Baldi, Professor, Department of Pharmaceutical Science and Technology, Maharaja Ranjit Singh Punjab Technical University, Bathinda (Punjab) India, EMail: baldiashish@gmail.com

Abstract

Drug utilization (DU) or Drug use evaluation (DUE) studies is an ongoing, authorized and systematic quality improvement process. These studies designed to review drug use and prescribing patterns of drug with current recommendations or guidelines for the treatment of a certain disease. DUE provide feedback of drug utilization data to prescribers related to number of cases of adverse effects adverse drug reactions, specific drug-drug, drug-food interactions and medication errors. This study shows the evaluation of current prescribing pattern to identify different adverse drug reactions, specific drug -drug, drug -food interactions and medication errors at tertiary care hospitals in Punjab.

Abbreviations: DU: Drug Utilization; DUE: Drug Use Evaluation; ARD: Adverse Drug Reaction; DI: Drug Interactions; ME: Medication Error

\section{Introduction}

Drug utilization (DU) or Drug use evaluation (DUE) studies is an ongoing, authorized and systematic quality improvement process. These studies designed to review drug use and prescribing patterns of drug with current recommendations or guidelines for the treatment of a certain disease. DUE provide feedback of drug utilization data to prescribers related to number of cases of adverse effects adverse drug reactions, specific drug-drug, drugfood interactions and medication errors [1]. This study shows the evaluation of current prescribing pattern to identify different adverse drug reactions, specific drug-drug, drug-food interactions and medication errors at tertiary care hospitals in Punjab. Drug interaction is defined as the modification of the effects of a drug (object drug) by the prior and/or the concomitant administration of another drug (precipitant drug). Drug interaction may either increase or decrease the intended effect of one or both drugs. It may transform the diagnostic, preventive or therapeutic activity of any drug [2]. Drug interactions can be an extremely main contributory factor for the incidence and occurrence of adverse drug reactions and adverse drug events. This article contains one part of the study which is accompanying with the adverse drug reactions, drug interactions, medication error reported during study period.

\section{Materials and Method}

The study was carried out on after obtaining approval and clearance from the Institutional Ethics Committee. The study was conducted at Department of Medicine in three different hospitals setting in the Moga, District of Punjab, India. Based on the inclusion and exclusion criteria the patient's after signing the Informed Consent Form data was collected from the patient case file, case reports, and laboratory reports. The study included patients with both type 1 and type 2 diabetes and suffering from hypertension with diabetic and hypertensive complications. Sample size is calculated through Software "Statcal Epiinfo" which is designed by US Department of Health and Social Services Centre for Disease Control and Prevention (CDC) for prospective observational studies [3]. Population size of the study was found to be $=1613254$ as per census (2011). Sample of the study was found to be $=1098$ Patients. Study was conducted for a period of one year. The aim of this study was to study the pattern, drugs involved, severity, outcomes and preventability of adverse drug reactions using intensive monitoring approach as well as to observe drug interactions and medication error. 


\section{Advanced Research in Gastroenterology \& Hepatology}

\section{Results}

Total 1208 patients of both genders were enrolled in study who were under treatment of diabetes and hypertension with their comorbidities and complications. During the study following ADR's10 were detected and reported. The present study showed that females experienced higher incidence of ADRs when compared to males. In most of the ADR cases immediately drug responsible for the causes of reaction were stopped \& management therapy were initiated as per guidance and guidelines. Type A reactions accounted for most of the ADRs. Using the Naranjo algorithm, (61.19\%) ADRs were assessed as 'probable' whereas (37.86\%) were assessed as 'possible' and $3(1 \%)$ were classified as 'definite' in relation to the suspected drug. Gastro-intestinal system was the most common organ system affected.

(Table 1-4)[4-21].

Table 1: ADR's reported

\begin{tabular}{|c|c|c|c|}
\hline Brand Name & Drug & Effect on Patients & Action Taken \\
\hline Inj. Emeset & Ondansetron & $\begin{array}{l}\text { Vomiting, Itching over face } \\
\text { and rashes }\end{array}$ & $\begin{array}{l}\text { Immediately drug stopped \& management therapy (i.e. Inj.Hydrocortisone, Inj. Avil \& } \\
\text { Inj. Rantac) initiated as per guidance }\end{array}$ \\
\hline Inj. Metrogyl & Metronidazole & $\begin{array}{l}\text { Difficulty in breathing, } \\
\text { vomiting }\end{array}$ & $\begin{array}{c}\text { Immediately drug stopped \& management therapy (i.e Inj. Hydrocortisone, Inj. Avil) } \\
\text { initiated as per guidance }\end{array}$ \\
\hline Inj. Taxel & Ranitidine & Diarrhea, vomiting & $\begin{array}{l}\text { Immediately drug stopped \& management therapy (i.e Inj. Octreotide) initiated as } \\
\text { per guidance }\end{array}$ \\
\hline Inj. Monocef & Ceftriaxone & $\begin{array}{l}\text { Vomiting, Nausea, Rashes } \\
\text { \& Redness }\end{array}$ & Immediately drug stopped \& management therapy initiated as per guidance \\
\hline Inj. Dynapar & Diclofenac & Rashes all over body & $\begin{array}{l}\text { Immediately drug stopped \& management therapy (i.e. Inj. Hydrocortisone, Inj. Avil } \\
\qquad \& \text { Inj. Rantac) initiated as per guidance }\end{array}$ \\
\hline Inj. Rantac & Ranitidine & Rashes all over body & Immediately drug stopped \& management therapy initiated as per guidance \\
\hline Inj. Drotin & Drotaverine & $\begin{array}{l}\text { Redness \& Itching all over } \\
\text { body }\end{array}$ & $\begin{array}{l}\text { Immediately drug stopped \& management therapy (i.e. Inj. Hydrocortisone, Inj. Avil) } \\
\text { initiated as per guidance }\end{array}$ \\
\hline Inj. Supacef & Cefuroxime & Itching \& Urticarial Rashes & Immediately drug stopped \& management therapy initiated as per guidance \\
\hline Cap. Citrol & $\begin{array}{l}\text { (Vit. D) Vitamin } \\
\text { supplements }\end{array}$ & $\begin{array}{l}\text { Cough, vomiting Difficulty } \\
\text { in swallowing, dizziness }\end{array}$ & Immediately drug stopped \& management therapy initiated as per guidance. \\
\hline Tab Livogen & $\begin{array}{l}\text { Folic acid and } \\
\text { ferrous fumarate }\end{array}$ & $\begin{array}{l}\text { Amenorrhea, fatigue and } \\
\text { headache, vomiting. }\end{array}$ & Immediately drug stopped \& management therapy initiated as per guidance \\
\hline
\end{tabular}

Table 2: Drug-drug interactions.

\begin{tabular}{|c|c|c|}
\hline Object Drug & $\begin{array}{l}\text { Interacting } \\
\text { Drug }\end{array}$ & Effect And Action Taken \\
\hline Carvedilol & Spironolactone & Hyperkalemia [2] \\
\hline Telmisartan & Aspirin & Hyperkalemia, diminish Antihypertensive effect [4] \\
\hline Telmisartan & Atorvastatin & Myopathy [5] \\
\hline Amiodarone & Warfarin & Risk of bleeding [6] \\
\hline Metoprolol & Aspirin & Diminish aspirin effect [7] \\
\hline Amiodarone & Metoprolol & Bradycardia \\
\hline Aspirin & Ramipril & Diminish antihypertensive effect [8] \\
\hline Spironolactone & Aspirin & Hyperkalemia [9] \\
\hline Diltiazem & Atorvastatin & Diltiazem increases level or effect of atorvastatin by affecting enzyme CYP3A4 metabolism. [10] \\
\hline Prednisolone & Levofloxacin & Co-administration of quinolone antibiotics and corticosteroids may increase risk of tendon rupture. [11] \\
\hline Phenytoin & Dexamethasone & $\begin{array}{l}\text { Phenytoin will decrease the level or effect of dexamethasone by affecting hepatic/intestinal enzyme CYP3A4 } \\
\text { metabolism. [12] }\end{array}$ \\
\hline Fenofibrate & Rosuvastatin & Fenofibrate may increase the risk for rhabdomyolysis when added to optimal statin regimen. [13] \\
\hline Furosemide & Amikacin & $\begin{array}{l}\text { Increase the risk of nephrotoxicity, Renal function test should be performed during therapy if co-administration } \\
\text { is necessary. [14] }\end{array}$ \\
\hline Furosemide & Cefoperazone & $\begin{array}{c}\text { Sr.Cr: }=1.5 \mathrm{mg} / \mathrm{dL} \text { (Increased from } 0.6 \mathrm{mg} / \mathrm{dL} \text { to } 1.5 \mathrm{mg} / \mathrm{dL} \text { ) and Sudden weight gain. Dose maintenance of } \\
\text { Cefoperazone, } 1.5 \mathrm{gm} \text { IV suggested. [15] }\end{array}$ \\
\hline
\end{tabular}




\section{Advanced Research in Gastroenterology \& Hepatology}

\begin{tabular}{|c|c|c|}
\hline Furosemide & Omeprazole & Hypomagnesemia,Irregular heart rhythm \& palpitation. Cap. Magnesium Sulphate added as supplement \\
\hline Furosemide & $\begin{array}{l}\text { Pyridoxine and } \\
\text { Amlodipine }\end{array}$ & $\begin{array}{l}\text { Dose of furosemide lead to decrease in potassium level, Hypokalemia was found. Spironolactone 100mg tablet } \\
\text { added to therapy as suggested. [16] }\end{array}$ \\
\hline Noradr & Insulin & ecreases the effect of insulin, so Monitor blood sugar level is s \\
\hline Insulin & $\begin{array}{l}\text { Levosalbutamol } \\
\text { \& ipratropium } \\
\text { bromide }\end{array}$ & $\begin{array}{c}\text { Decreases the effect of insulin leading to increase in the blood glucose level, so Monitor blood glucose level is } \\
\text { suggested. [18] }\end{array}$ \\
\hline Carbamazepine & Toperamide & $\begin{array}{l}\text { Stevens-Johnson Syndrome. Patient was previously taking toperamide for the indication of epilepsy. So drug } \\
\text { stopped. [19] }\end{array}$ \\
\hline
\end{tabular}

Table 3: Drug-food interactions.

\begin{tabular}{|c|c|c|}
\hline Drug & Food & Effect \\
\hline Naproxen & Fatty food & Upset stomach [2] \\
\hline Celecoxib & Milk & Inhibit the enzyme involve in BZD metabolism [2] \\
\hline Benzodiazepine & Grapefruit & Reduce the effect of drug [5] \\
\hline Warfarin & Vitamin K & Reduce the absorption of drug [6] \\
\hline Tetracycline & Calcium food & Liver damage [20] \\
\hline Acetaminophen & Alcohol & Decrease the absorption of drug [21] \\
\hline Digoxin & Oatmeal & \\
\hline
\end{tabular}

Table 4: Medication errors reported.

\begin{tabular}{|c|c|c|c|}
\hline Incident & Type of Error & RCA & Preventive Action \\
\hline $\begin{array}{c}\text { Tab. Alprax 0.25mg prescribed, pharmacist dispense } \\
\text { Alprax 0.5mg }\end{array}$ & Dispensing error [18] & Wrong dose & Pharmacist counselled \\
\hline $\begin{array}{c}\text { Inj. Novomix 30mg prescribed and Nursing staff indented } \\
\text { Novaplus 75mg }\end{array}$ & Indenting error [19] & Wrong drug & Training provided to Nursing staff \\
\hline $\begin{array}{c}\text { Tab. Naxpro RD 40mg prescribed and available in } \\
\text { hospital store but not dispensed }\end{array}$ & Dispensing error [18] & Not dispense & Pharmacist counselled \\
\hline Tab. Arkamin prescribed and Amikacin dispensed & Dispensing error [18] & Wrong drug & Pharmacist counselled \\
\hline Tb Acitrom prescribed but Acaitretin dispensed & Dispensing error [19] & Wrong drug & Double check process initiated. \\
\hline
\end{tabular}

\section{Discussion}

During the study it was found that dispensing type of error is the common followed by indenting error. It is important to understand that an analysis of medication errors can help healthcare professionals and pharmacist to identify why medication errors can occur and make improvements to prevent or reduce them. Future research into the development of a clinical framework to prevent clinical errors is required. More data in regards to medication and other clinical errors and what causes them is essential. In addition, data concerning potential solutions is also recommended and the articles could be analyzed further based on location of the medical error incident (e.g. hospital, primary care, etc).

In most of the ADR cases immediately drug responsible for the causes of reaction were stopped \& management therapy were initiated as per guidance and guidelines. Type A reactions accounted for most of the ADRs. Using the Naranjo algorithm, (61.19\%) ADRs were assessed as 'probable' whereas (37.86\%) were assessed as 'possible' and 3(1\%) were classified as 'definite' in relation to the suspected drug similar results were found in study conducted by [16]. Gastro-intestinal system was the most common organ system affected. Sign and symptoms related to gastro-intestinal system were vomiting, diarrhea, constipation, nausea, Gastritis, peptic ulcer, and gastric pain. When organ systems affected were studied, Gastro-intestinal system was the organ system most commonly affected by the ADRs with vomiting as the most common individual reaction. This study showed the level of gastric intolerance of patients to this class of drugs [22].

These findings substantiate previously reported studies on gastric ADRs [23]. In most of the ADRs cases drug were withdrawn instead of dose alteration or alternative therapy. The present study showed that females experienced higher incidence of ADRs when compared to males which is similar to the results of [24] Cardiovascular drugs were the second most common drug class with furosemide being the most commonly implicated drug. These findings are consistent with the findings of [25]. During the study it 
was found that percentage of the reactions was severe in nature and mostly skin reactions accounted for that. Preventable ADRs were less in this study compared to available reports [14].

\section{Conclusion}

With this study it was concluded that there is an alarming rate of prevalence and incident of adverse drug reactions, drug interactions, medication error which is much higher in patients receiving combinations of drugs or poly pharmacy or suffered from co-morbidity of diseases such as diabetes, hypertension which require prolong and multi treatments and the risk of drug interaction will increase as they are treated with multi-therapies. The intensive monitoring of ADRs in medicine wards helped to assess the incidence and pattern of ADRs.

It is well reported that diabetic patients are suffering because of higher risk of diabetic complications may encounter higher rate of drug interaction as they receive combination of therapies, and hence the rate of occurrence of drug interaction is rapidly increases. In this study, we have found that the patients receiving diabetic medication are at higher risk of drug-drug and drug-food interactions as they are receiving multi therapies for the treatment of diabetic complications and other related disorders. So that the physician and other medical staff should aware and guide the patient about the medication, drug related problems, interaction with food and other drugs or with medication.

This will help to avoid and stop the rate of the drug-drug and drug-food interactions associated to anti diabetic therapy. This study summarized and highlights the various drug interactions likely drug-drug and drug-food interactions as well as reports unwanted effects of other treatment associated with diabetic and hypertensive patients suffering with their complications.

Clinical pharmacists design pharmaceutical care plan, identify problems, establish outcome goals, provide patient counseling, monitor pharmacokinetics and therapeutic drug level, report adverse drug reaction (ADRs), evaluate treatment outcome, and drug information to health care professionals.

\section{Limitations of the Study}

Rechallenge was not performed for many ADR cases and this might alter the causality if such information is available for all the cases.

\section{References}

1. Serradell J, Bjornson DC, Hartzema AG (1987) Drug utilization study methodologies: national and international perspectives. Drug Intell Clin Pharm 21(12): 994-1001.

2. Sharma G, Harikumar SL, Navis S (2015) A review on drug-drug and drug-food interactions in patients during the treatment of diabetes mellitus. International Journal of Pharmacology and Clinical Sciences 4(4): 98-105.

3. Cooper Dehoff RM, Bird ST, Nichols GA, Delaney JA, Winterstein AG (2013) Antihypertensive drug class interactions and risk for incident a nested case-control study J Am Heart Assoc 2(3): e000125.
4. Datta S, Udupa AL (2010) Antihypertensive drug use in patients having comorbid diabetes : cross sectional prescription pattern study in a tertiary care hospital 3(4): 43-45.

5. Samardzic I (2015) Incidence of potential drug-drug interactions with antidiabetic drugs. Pharmazie 70(6): 410-415.

6. Huri HZ, Wee HF (2013) Drug related problems in type 2 diabetes patients with hypertension: a cross-sectional retrospective study. BMC Endocrine Disorders 13: 2.

7. Das P, Das BP, Rauniar GP, Roy RK, Sharma SK (2011) Drug utilization pattern and effectiveness analysis in diabetes mellitus at a tertiary care centre in Eastern Nepal. Indian J Physiol Pharmacol 55(3): 272-280.

8. Triplitt C (2006) Drug interactions of medications commonly used in diabetes. Diabetes Spectrum 19(4): 202-211.

9. Schartz SN, Weber RJ (2015) Adverse drug reactions. Psap, pp. 5-26.

10. Sharma R, Dogra D, Dogra N (2015) A study of cutaneous adverse drug reactions at a tertiary center in Jammu, India. Indian Dermatology Online Jounal 6(3): 68-75.

11. Denham MJ (1990) Adverse drug reactions. British Medical Bulletin 46(1): 53-62.

12. Gor AP, Desai SV (2008) Adverse drug reactions (ADR) in the inpatients of medicine department of a rural tertiary care teaching hospital and influence of pharmacovigilance in reporting ADR. Indian J Pharmacol 40(1): $37-40$.

13. Carandang RR, Cao K, Jose NB, Almonte FD, Tinio RM (2015) Knowledge and attitudes on adverse drug reaction reporting of selected hospitalbased health practitioners in manila, Philippines. Sch Acad J Pharm 4(6): 301-307.

14. Palanisamy S, Kumaran A, Rajasekaran A (2011) A study on assessment, monitoring and reporting of adverse drug reactions in indian hospital. Asian Journal of Pharmaceutical and Clinical Research 4(3): 112-116.

15. Pallasch TJ (1989) Principles of pharmacotherapy. V. toxicology and adverse drug reactions. Anesth Prog 36: 41-45.

16. McEvoy DS, Sittig DF, Hickman TT, Aaron S, Ai A, et al. (2017) Variation in high-priority drug-drug interaction alerts across institutions and electronic health records. J Am Med Informatics Assoc 24(2): 331-338.

17. Saini VK, Sewal RK, Ahmad Y, Medhi B (205) Prospective observational study of adverse drug reactions of anticancer drugs used in cancer treatment in a tertiary care hospital. Indian J Pharm Sci 77(6): 687693.

18. Hermon R, Williams PAH (2013) A study on information induced medication errors.

19. Greenwald J, Denham C, Jack B (2007) The hospital discharge: a review of a high risk care transition with highlights of a reengineered discharge process. J Patient Saf 3(2): 97-106.

20. Amin AJ, Prashant CS, Pratik DA, Prakash M, Vinob K, et al. (2015) Drug utilization study of antimicrobial agents in patients of neonatal sepsis in neonatal intensive care unit at a tertiary care hospital in western part of India. International Journal of Basic \& Clinical Pharmacology 4(5): 895-902.

21. Sutharson L, Hariharan RS, Vamsadhara C (2003) Drug utilization study in diabetology outpatient setting of A tertiary hospital. Indian Journal of Pharmacology 35: 237-240.

22. Board BMA (2006) Reporting adverse drug reactions a guide for healthcare professionals. BMA Board Science, UK, pp. 1-36.

23. Shrivastava M, Uchit G, Chakravarti A, Joshi G, Mahatme M, et al. (2011) Adverse drug reactions reported in Indira Gandhi Government Medical College and Hospital, Nagpur. J Assoc Physicians India 59: 296-299. 
24. Carrasco GP, Hernández BV, Esteban HJ, Jiménez TI, Álvaro MA, et al (2017) Adverse drug reactions to anticoagulants in Spain: analysis of the Spanish National Hospital Discharge Data (2010-2013). BMJ Open $7(1)$.
25. Dhar K, Akanksha S, Preeti G, Rajkumar G, Chopra VS, et al. (2015) Pattern of adverse drug reactions to antibiotics commonly prescribed in department of medicine and pediatrics in a tertiary care teaching hospital, Ghaziabad. J Appl Pharm Sci 5(4): 78-82.

\section{Your next submission with Juniper Publishers will reach you the below assets}

- Quality Editorial service

- Swift Peer Review

- Reprints availability

- E-prints Service

- Manuscript Podcast for convenient understanding

- Global attainment for your research

- Manuscript accessibility in different formats ( Pdf, E-pub, Full Text, Audio)

- Unceasing customer service

Track the below URL for one-step submission https://juniperpublishers.com/online-submission.php 